\title{
Factors Affecting Continuous Usage Intention of Mobile Banking in Tema and Kumasi
}

\author{
Philip Avornyo \\ Jiaming Fang" \\ Ransford Okoe Odai \\ Joshua Ben Vondee \\ School of Management and Economics \\ University of Electronic Science and Technology of China \\ No.2006, Xiyuan Ave, West Hi-Tech Zone, Chengdu \\ Sichuan, China, 611731. \\ Michael Nartei Nartey \\ Chengdu University \\ No.1 Upper Section of Shiling Street, Chengluo Road \\ Chengdu City Sichuan Province, 610106 \\ P. R. China
}

\begin{abstract}
This paper examines the antecedents of continuous usage intention of Mobile Banking of customers of banks in Tema and Kumasi, Ghana. In addition, the study ascertains whether antecedents of IS acceptance and those of IS continuous usage intention can coexist to jointly predict continuous usage of Mobile Banking. The study further enhances the understanding of personality traits as antecedents of continuous usage intention of Mobile Banking. A research model is designed and developed by integrating some dimensions of TAM and ECM and two personality traits namely, Perceived Enjoyment and Perceived Innovativeness. Data was collected from 295Mobile Banking users of banks based in Tema and Kumasi. Structural Equation Modeling technique was used to test and assess the validity of the hypothesized relationships in the model. The results indicate that Satisfaction, Perceived Enjoyment and Perceived Usefulness positively predict customers' Continuous Usage Intention of Mobile Banking. However, Perceived Ease of Use and Personal Innovativeness did not have significant effect on Mobile Banking Continuous Usage Intention. Premised on these findings, this study suggests that banks need to improve Mobile Banking to ensure users can enjoy and have good experience in the course of performing task related to banking services. Furthermore, the paper recommends future studies to separate antecedents of acceptance from antecedents of continuous usage intention in investigating factors that influence Mobile Banking Continuous Usage Intention.
\end{abstract}

Keywords: Perceived Usefulness, Personality trait, Perceived Innovativeness, Satisfaction, Mobile Banking Continuous Usage Intentions.

\section{Introduction}

Over the last decade, the banking sector is provided with a remarkable opportunity through Mobile Banking due to the rapid advancement of mobile devices' technology (Luarn \& Lin, 2005; Aijaz A. Shaikh \& Karjaluoto, 2014; Tam \& Oliveira, 2017; Tran \& Corner, 2016; Zhang, Lu, \& Kizildag, 2018). Mobile Banking is defined as a channel (Tran and Corner, 2016) whereby the customer interacts with a bank via a mobile device, such as a mobile phone or personal digital assistance (PDA) (Barnes \& Corbitt, 2003). Financial institution particularly for the purpose of this research the banking sector, offers services or products through M-banking channels to/from customers on their portable technologies or mobile devices. The proliferation of Mobile Banking services has necessitated for customers to be able to execute several banking activities including checking balance, transferring funds, depositing checks, trading stocks and many other financial or non-financial banking services (Aijaz A. Shaikh \& Karjaluoto, 2015; Aijaz A. Shaikh, Karjaluoto, \& Chinje, 2015b; Zhang et al., 2018) spreading throughout both developed and developing world (Safeena, Rahmath; Date, Hema;Kammani, Abdullaj; Hundewale, 2012; Tran \& Corner, 2016). The number of people relying on mobile devices for banking services is increasing as compare to that of services at the physical banks (Srivastava, 2013). 
According to Economist (Economist, May 2018a), setup of physical bank branches and ATMs can be very expensive in areas particularly hinterlands and rural communities, however, thanks to Mobile Banking and mobile payment, the number of people without access to banking services fell from 2.5 billion in 2011 to 1.7 billion in 2017. Interestingly, Findex of World Bank noticed in early 2018 that globally only 69\% of adults own mobile-money and bank (including financial institution such as savings \& loans companies) accounts.

However, it is estimated that mobile phone especially smartphone users in Africa for instance will increase from 7.2 million as at 2013 to 525 million by 2020 (Danquah \& Iddrisu, 2018). It is also noticed further that $78 \%$ of wageearners around the world are without bank account, yet possess mobile phones, which is an indication of the huge market potential for Mobile Banking services(Muhammad Al Amine, 2016; World-Bank, 2018). The convenience of Mobile Banking has opened the avenue for banks to provide customers with the ability to virtually bank from anywhere and at any time, and to retain them (Baptista \& Oliveira, 2017; Berraies, Yahia, \& Hannachi, 2017). Again, banks through this channel are able to safeguard customers against competitors (Berraies et al., 2017).

In Ghana, the number of fully registered Mobile Banking users grew from 1,449,374 users in 2015 to 2,110,984 users by 2017(BOG, 2017). Earlier study by Crabbe et al. (2009) realized that Ghana's mobile technologies have more internet access than that of desktop computers. The users of mobile devices use the internet/data access for services and products such as Mobile Banking services. This significant growth however comes with its challenges to bank managers in long-term sustenance and success of any information systems as argued by (Bhattacherjee, 2001) depends on, its adoption(Crabbe et al., 2009b; Cudjoe, Anim, \& Tetteh Nyanyofio, 2015; Shareef, Baabdullah, Dutta, Kumar, \& Dwivedi, 2018; SooCheong (Shawn) Jang, 2009) and its continuous usage(Adapa and Roy, 2017; Gumussoy, 2016; Shaikh, 2016; Zhou and Liu, 2014). Crucially, retention of existing users to continue the use of Mobile Banking encompasses strategic and economic benefits (Albashrawi \& Motiwalla, 2017) as well as a source of competitive advantage to the bank(Yuan, Liu, Yao, \& Liu, 2014). For instance, the total volume of Mobile Banking transactions according to BOG (2017), increased from 5,440,387 in 2015 to 7,036,285 in 2017 with a corresponding positive impact on the value of transactions. Albashrawi \& Motiwalla (2017) agreed to a report by Fiserv, 2014 that when users continue to patronize Mobile Banking, the payoffs are higher in that, for instance, banks generate revenue (Cudjoe et al., 2015) from the services users subscribe to or purchase from the Mobile Banking platform. Consequently, when interest of users after the initial acceptance and gaining usage experience of Mobile Banking reduces, it could lead to less usage of Mobile Banking services and eventually discontinue its usage(Yuan et al., 2014). In such situation, banks begin to worry about the huge investment they make into the Mobile Banking system's development and the undesirable effect the loss of loyal Mobile Banking customers could have on their revenue stream. This shows how important it is to retain existing customers as the cost incurred in acquiring a new customer is higher than maintaining an existing one (Bhattacherjee, 2001). These concerns and the fact that accessibility of Mobile Banking has been increasing over the years with its progressive technological advancement, yet, the number of users to continue its use has not met expectations (Dineshwar \& Steven, 2013; Hanafizadeh, Behboudi, Abedini Koshksaray, \& Jalilvand Shirkhani Tabar, 2014; Mohammadi, 2015), are necessitating for the recent upsurge in research on thorough investigations on the antecedents that actually determine the intention to continuously use Mobile Banking.

As more and more IS researchers are becoming aware and seeing the importance of users' continuous usage of IS in general for that matter Mobile Banking in both advanced and emerging countries, little attention is given to exploring the driving determinants that lead to customers' Continuous Usage Intention of Mobile Banking in developing countries such as Ghana (Laukkanen, 2016; A. Shaikh, 2016). Meanwhile, according to Global Findex Report of the World Bank (2018), 42.3\% of Ghana's total adult population own financial institution account (i.e. majority of these adults are in the banking sector which forms over $80 \%$ of the financial institution in Ghana (BOG, 2018a)) as at first quarter of 2018 and an estimated 12.5million bank accounts exist as at end of 2017(BOG, 2017). It is also noteworthy to state that a surge in number of mobile money/payment (network operator/information technologies like 3G) subscriptions could facilitate growth in Mobile Banking usage services (Arcand, PromTep, Brun, \& Rajaobelina, 2017; Scornavacca \& Barnes, 2004; Scornavacca \& Hoehle, 2007). it is noticed in BOG (2017) that average volume of Mobile Banking transactions per day in 2015 (i.e. 29,729 transactions) was higher than that of 2017 (19,277 transactions), an indication of less active users for Mobile Banking services in Ghana as the years go by while growth in its subscription keeps increasing.

Meanwhile, in terms of delivery of banking services to meeting customers' needs, banks are taking advantage of the fast-mobile phone penetration, to reach out through Mobile Banking platforms. Banks are able to provide services such as inward remittances, transfer funds, bill payments, account balance enquiry, mobile top-ups and alert notification (BOG, 2017; Kwateng et al., 2018; Shaikh and Karjaluoto, 2014). Banks including Ecobank, GT Bank and First Atlantic Bank with Mobile Banking products Bond4All, myghpay.com and Purple pay respectively offer interesting Mobile Banking services. 
Although, banks in Ghana are putting in the necessary efforts on a daily bases in advertising to both existing and potential customers (Kwateng et al., 2018), little impact is made to keep customers to continuously use the Mobile Banking services. Based on these circumstances which keep arising in the arena of Mobile Banking, the objective of the study is therefore to enhance the understanding of the factors that determine the intention of customers to continuously use Mobile Banking, particularly in Ghana.

Majority of the studies on continuous usage intention, considered various kinds of models and theories particularly, ECM by Bhattacherjee (2001) while little attention is given to Personality Traits (Aldás-Manzano, Ruiz-Mafé, \& SanzBlas, 2009; J. C. Hong, Lin, \& Hsieh, 2016; Z. Lin \& Filieri, 2015; Mahatanankoon, 2007). Moreover over, other studies equally used technology adoption theories and models such as Technology Acceptance Model (TAM) by Davis, (1986). TAM has been confirmed in several studies of predicting both acceptance/adoption and continuous intention in IS, and ECM predicting continuous intention in IS related fields in this case Mobile Banking (Tam \& Oliveira, 2017). However, TAM and ECM are said to be value-based models which predict the use of Mobile Banking services through the eyes of extrinsic motivations (Albashrawi \& Motiwalla, 2017). Meanwhile, it is empirically argued that Personality Traits, refer to as the enduring predispositions of individuals to respond to stimuli across situations (Gu et al., 2018; Thatcher \& Perrewe, 2002) predicting through the eyes of intrinsic motivations, also play key role in studies on behavioral continuous intentions (Z. Lin \& Filieri, 2015). Several studies have shown the significance of presenting personality traits -i.e. Perceived Enjoyment/playfulness (i.e. enjoyment is same as playfulness from Lin et al. (2005) and Personal Innovativeness as important determinants of predicting behavioral intention (R. Gu et al., 2018; Lu, 2014; Mahatanankoon, 2007; Natarajan, Balasubramanian, \& Kasilingam, 2018).

Despite, mounting evidence suggests that Perceived Innovativeness and Perceived Enjoyment positively relate to usage intention of IS, they have not been given much consideration to enhance the understanding from all viewpoints. In fact, Lin et al. (2005) puts it that while Personality Traits of individuals are presented from intrinsic point of view, TAM actually presents beliefs from extrinsic point of view. Kim, (2010), Thong et al.(2006) and Deci and Ryan (1985) revealed that people are generally motivated both extrinsically and intrinsically, hence it is necessary to consider both motivations in studies for a more elaborative theoretical framework on Mobile Banking Continuous Usage Intention. (Aldás-Manzano et al., 2009) explained lucidly that, if the intrinsic perceptions (Perceived Innovativeness and Perceived Enjoyment) that motivate individuals to use IS services are as important as those of extrinsic ones, then bank managers should not just design Mobile Banking services that are only easy to use or useful but must be enjoyable as well. Furthermore, in most of the studies conducted there seems to be lack of understanding on whether antecedents of adoption and those of continuous usage intention can coexist (or jointly)in predicting continuous usage intention. In addressing these gaps, first, the study focuses on Ghana and second, proposes a theoretical framework which integrates TAM and ECM (i.e. Perceived Usefulness, Perceived Ease of Use and Satisfaction) with Personality Traits (i.e. Perceived Enjoyment and Personal Innovativeness(Agarwal and Prasad, 1998)) to further help explain the antecedents that determine customers' continuous intention to use Mobile Banking and also ascertain whether antecedents of adoption should be separated from those of continuous usage intention in further studies.

The rest of this study is organized in the following structure: Literature review is presented in the next section, followed by research model and hypotheses formulation then research method. After this, data analysis and hypothesis testing followed then results and discussion form the next section. The final sections consist of conclusion, theoretical and practical implications, limitations and future research directions.

\section{Literature review}

\section{Studies on Mobile Banking in both developed and developing countries}

Extant research on Mobile Banking from any geographical location published in major journals show that there are about 55 articles (based on the keyword "M-Banking" used for the search) in all the journals between January, 2005 and March 2014 (Shaikh and Karjaluoto, 2014). Among these studies, Intention to Use (INT) and Attitude (ATT) stood out as the main dependent variables. Similarly, Tam \& Oliveira (2017) generated 64 articles across the world which investigated and contributed on M-Banking between January, 2002 and July, 2016. Interestingly, behavioral intention or intention to use is actually considered as either acceptance/adoption or continuous in the studies on M-Banking apart from the work of Shaikh and Karjaluoto (2014) who excluded studies on Continuous Usage Intention of Mobile Banking in their research work. For instance, (Afshan and Sharif, 2016; Gu et al., 2009; Lin, 2011) considered behavioral intention to adopt as the dependent variable while Shaikh and Karjaluoto (2016), Susanto et al, (2016) and (Yuan et al., 2014) considered behavioral intention to continue m-banking usage as the dependent variable. 
According to Shaikh and Karjaluoto (2014), 16\% of the 55 studies on Mobile Banking were conducted in developed countries (such as Finland, Germany and UK) while 84\% conducted in developing countries (such as Ghana, Malaysia and China). In a similar vein, Tam \& Oliveira (2017)indicated that their study cut across all geographical location. Despite the increasing number of studies focusing on investigating factors affecting both Mobile Banking acceptance/adoption and continuous usage intention across the globe, majority of the studies on Mobile Banking in Ghana focused mainly on investigating factors affecting the acceptance/adoption of Mobile Banking with less emphasis on studying the factors that affect Continuous Usage Intention of Mobile Banking. Kwateng et al. (2018) and Crabbe et al. (2009) for instance, did comprehensive studies to find out the main antecedents that determine the acceptance and eventual use of Mobile Banking services in Ghana. Bhattacherjee (2001) however, reiterated that users' reevaluation of their acceptance of an IS before subsequently continue to use it, is an important stage in the process of studying continuous intention of the IS.

On this note, the study by Kwateng et al. (2018) on users of Mobile Banking in Ghana found price value, habit and trust as the main antecedents that determine the acceptance and eventual use of Mobile Banking services in Ghana. Similarly, Crabbe et al. (2009) examined the impact of social and cultural factors on adoption of Mobile Banking in Ghana and found that Perceived Usefulness, perceived elitisation, facilitating conditions and Perceived credibility have profound effect on Mobile Banking adoption in Ghana. Crabbe et al. (2009) further showed that sustained usage of Mobile Banking is based on its usefulness while Kwateng et al. (2018) highlighted, habit and behavioral intention to adopt as the factors that impact the actual usage of Mobile Banking in Ghana. From the perspective of barriers in adopting Mobile Banking, Iddris (2013) realized that attracting additional service charges and requirement of extra knowledge are the main roadblocks that affect adoption of Mobile Banking in Ghana. Another comprehensive study by Cudjoe et al. (2015) on customers of Access bank in Ghana indicated Perceived Usefulness, Perceived Ease of Use , Perceived Financial Cost and Perceived Credibility as significant factors that impact on their adoption of Mobile Banking. The researchers also further found that Perceived Financial Cost and Perceived Credibility happen to be the main setbacks for behavioral intention of the customers to adopt Mobile Banking in Ghana. Meanwhile, the studies of Kwateng et al. (2018) and Crabbe et al. (2009) revealed the significance of social and cultural features which was due to the consideration of demographic factors in both studies.

\section{Mobile Banking Continuous Usage Intention}

Quite recently, the rapid advancement and innovations in Mobile Banking all over the world (Shaikh and Karjaluoto, 2016) is championing its high importance and recognition in industries as well as academia. As a result, there have been growing number of studies across different research context focusing on factors that determine Mobile Banking Continuous Usage Intention(Al-Ghazali et al., 2015; Gumussoy, 2016; Jamshidi et al., 2018; Jusuf et al., 2017; Rejikumar and Sudharani, 2012; Yu and Fang, 2009; Zhou and Liu, 2014) defined in Albashrawi and Motiwalla (2017) as the intent to continue using Mobile Banking after the initial adoption phase. Already established theories and models related to information technology such as TAM Davis (1989) and ECM (Bhattacherjee, 2001) are often used as the bases from which frameworks of the studies are derived. The constructs including Perceived Usefulness, Perceived Ease of Use and Satisfaction happened to be the domineering predictors of Mobile Banking Continuous Usage Intention whenever TAM and ECM are incorporated. For instance Jusuf et al. (2017), Yuan et al. (2014) and Zhou and Liu (2014) found direct impact of Perceived Usefulness and Satisfaction on the intention of Mobile Banking continuous usage. Albashrawi and Motiwalla (2017) and Reji kumar and Sudharani (2012), noticed Perceived Usefulness positively impacts Satisfaction which is an antecedent that predicts Mobile Banking Continuous Usage Intention. Most of the researchers such as Yuan et al. (2014) in further enhancement of the models for better understanding empirically introduced established factors and argued that there is respectively significant positive and negative impact on Perceived task-technology fit and Perceived risk on Mobile Banking Continuous Usage Intention. Similarly, Susanto et al. (2016) examined the impact Perceived Security as well as Privacy have on Trust which further impacts Satisfaction of members of Macromill Embrain research company who are users of smartphone Mobile Banking services in South Korea and their Satisfaction directly influence Mobile Banking Continuous Usage Intention.

Having noticed ECM as a dominant model in the various studies on Continuous Usage Intention of Mobile Banking, it is noticed that it misses to account for the effect of other empirically observed factors such as Perceived Enjoyment and Perceived Innovativeness. In fact, Perceived Enjoyment and Perceived Innovativeness have been found to impact continuous intention in many different IT related context (Choi et al., 2011; Xu and Gupta, 2009). It shows how important these two factors are, yet, are not represented in the extended models developed for the various studies on Mobile Banking Continuous Usage Intention. 
Actually, the exhibition and significance of Perceived Innovativeness as well as its accompanying Perceived Enjoyment to determine Satisfaction have made both determinants of continuous intention to receive much emphasis in previous IT related studies (Aldás-Manzano et al., 2009; Gan and Li, 2018; Hong et al., 2016; Joo et al., 2014; Kim, 2010; Kim et al., 2016). A thorough review of literature on Mobile Banking Continuous Usage Intention shows less attention on these two determinants in supporting the well-recognized models in enhancing the understanding of the main factors of Mobile Banking Continuous Usage Intention.

\section{Expectation-Confirmation and Technology Acceptance Models (ECM and TAM)}

The ECM and TAM have widely been used to study continuous intention of several information systems (IS) (Boakye et al., 2012; Hong et al., 2006; Thong et al., 2006; Yuan et al., 2014). In the study of determinants of Continuous Usage Intention of Mobile Banking either the ECM, TAM or a combination of both are considered in providing a better predictive strength (Albashrawi \& Motiwalla, 2017). Bhattacherjee (2001) formulated and proposed ECM from ECT (what is ECT?) which in general was widely used in literature on consumer behavior to study Satisfaction, service marketing and post-purchase behavior such as complains and repurchase.

The predictive power of ECT has been shown in many different contexts, however, after observing several debates with regards to the context within which ECT operates, Bhattacherjee (2001) proposed ECM. The ECM suggested that Confirmation and Perceived Usefulness are the main determinants of Satisfaction while Satisfaction in turn is the major predictor of continuous usage intention of IS. A substantial research work has since been carried out in the field of IS using ECM success model to understand continuous usage intention. As Bhattacherjee (2001) empirically validated from the ECM that both Perceived Usefulness as a determinant and Satisfaction as a major predictor of continuous usage intention of IS, and having noticed their significance in previous studies on Mobile Banking, this current study employs Perceived Usefulness and Satisfaction to enhance the understanding of Mobile Banking users' continuous usage intention.

Meanwhile, Davis (1989) developed TAM to help in examining the factors that determine intention of users to adopt IS after concerns were raised on finding out why workers were not interested in accepting to use IS made available to them (Holden and Karsh, 2010). The model was adapted from the Theory of Reasoned Action (Fishbein and Ajzen, 1975; Ajzen and Fishbein, 1980) which states that attitude and subjective norm concerning a behavior are internal variables that influence the intention to perform that behavior which in turn affects the actual behavior. However, the Theory of Reasoned Action (TRA) as a theoretical backdrop for modeling TAM, could not capture external variables that influence the internal variables, this led Davis (1989) and (Davis et al. (1989) to formulate TAM. TAM has it that an individual's intention to accept a technology is dependent on the behavioral intention of the person which through the person's attitude in turn depends on two other factors namely, Perceived Usefulness and Perceived Ease of Use (Liu et al., 2009; Kwateng et al., 2018). Perceived Usefulness is found to directly impact behavioral intention and subsequently serves as a mediating factor in the relation between Perceived Ease of Use and behavioral intention while, Perceived Ease of Use significantly impacts Perceived Usefulness. The parsimony and simplicity of TAM over other models have paved the way for it to be widely used in several studies on IS (Arahita and Hatammimi, 2015; Farah et al., 2018; Gefen and Straub, 2003; Mha, 2015; Kwateng et al., 2018; Tam \& Oliveira, 2017). Among the comprehensive studies on IS that used TAM, those on Mobile Banking Continuous Usage Intention are not left out. TAM's propensity in examining the factors that influence Mobile Banking continuous or post adoption usage intention has been realized in considerable number of research works including that of Reji kumar and Sudharani (2012), Amin et al. (2012), Yuan et al. (2014) and Albashrawi \& Motiwalla (2017). These studies have pointed the significance of Perceived Usefulness and Perceived Ease of Use in either directly or indirectly influencing continuous usage intention particularly in the context of Mobile Banking.

Hence, it becomes necessary to consider Perceived Usefulness and Perceived Ease of Use of TAM and some dimensions of ECM as mentioned earlier with Perceived Enjoyment and Personal Innovativeness as personality traits to enhance the understanding of the antecedents of Mobile Banking Continuous Usage Intention and also find out if the determinants of IS acceptance and existing determinants of IS continuous intention can coexist (or jointly) to predict IS continuous usage intention for that matter Mobile Banking Continuous Usage Intention.

\section{Personal Innovativeness}

In essence, Personal Innovativeness which refers to the tendency of an individual to be willing to embrace change and try out new things in the field of information technology (Agarwal and Prasad, 1998; Thatcher and Perrewe, 2002), has received numerous attentions in various studies (Gu et al., 2018; Lin and Filieri, 2015). It is classified into either global personal trait level or domain specific personal trait level (Lin and Filieri, 2015; Lu, 2014; Thatcher \& Perrewe, 2002). 
In line with many IS related studies (Gu et al., 2018), this study conceptualizes Personal Innovativeness as a domainspecific trait since it is enduring and predisposes individuals to respond to stimuli in a consistent manner within a narrowly defined context. (Thatcher \& Perrewe, 2002). Agarwal and Prasad (1998) drew from the theory of Diffusion of Innovations that users with high level of Personal Innovativeness are susceptible in adjusting to innovations earlier than those without. Joo et al. (2014) and Liu et al. (2010) examined the effect of Personal Innovativeness in mobile learning behavior of students then found that students with high levels of innovativeness positively perceived the usefulness and ease of use of mobile learning and also demonstrated more intention to use mobile learning. Similar studies cut across different disciplines including mobile commerce (Lu, 2014), Social Network Sites (Wijesundara and Xixiang, 2018) and Sales technology (Schillewaert et al., 2005), signifying the importance of it. Personal Innovativeness as stated by Thatcher and Perrewe (2002), actually shapes the capabilities of individuals' perception to understand and be able to adjust to the changes in new information technology (Lin and Filieri, 2015; Rogers, 1995). Hence, it's necessary to investigate the impact of Personal Innovativeness on Mobile Banking Continuous Usage Intention.

\section{Perceived Enjoyment}

Perceived Enjoyment also as a personality trait pertains to the perception of an individual deriving pleasant and fun from performing a behavior which is satisfying (Gallego et al., 2016; Hsu and Lu, 2007).Studies have shown that Perceived Enjoyment of individuals increase the continuous intention to use IS such that users with high Perceived Enjoyment impacts positively in determining continuous usage intention of Wechat app (Gan and Li, 2018). Gan and Li (2018) supports the findings of Deci and Ryan (2000) that Perceived Enjoyment is a major motivating predictor of social media usage. In the study of investigating factors that determine participation in online community games, Hsu and Lu (2007) noticed that Perceived Enjoyment plays a very important intrinsic and motivating role to predict customer loyalty. Kim et al. (2016) also agrees that along with Perceived Usefulness as an extrinsic motivation, Perceived Enjoyment is an intrinsic motivation which is a major determining factor in predicting information technology usage intention. Previous studies such as Davis et al (1992) and Teo et al. (1999) who also found the significant effect Perceived Enjoyment had on computer and internet usage, calls for Perceived Enjoyment to be considered to further give a clear picture of factors that determine continuous usage intention particularly of Mobile Banking for the purposes of this study.

\section{Research model and hypotheses}

\section{Perceived Usefulness}

Perceived Usefulness in the context of Mobile Banking examines the degree to which an individual can use Mobile Banking to improve conducting banking services (Albashrawi and Motiwalla, 2017; Davis, 1989). Several studies in IS have found it to possess a predictive ability on Satisfaction such as in the context of web portal (Lin et al., 2005), mobile internet(S. J. Hong et al., 2006) and Mobile Banking (Albashrawi \& Motiwalla, 2017), and also on continuous intention in the context of web-enabled mobile phone service (Boakye et al., 2012), web portal (Lin et al., 2005), knowledge creation (Chou et al., 2009), e-learning (Lin and Wang, 2012), instant messaging (Wang et al., 2012), online travel services (Li and Liu, 2014), Furthermore, Yuan et al. (2014), Susanto et al. (2016) and Jusuf et al. (2017) realized in the context of Mobile Banking that Perceived Usefulness predicts continuous intention. Thus, we hypothesize that:

H1a: Perceived Usefulness is positively related to Continuous Usage Intention of Mobile Banking users

H1b: Perceived Usefulness is positively related to Satisfaction

\section{Perceived Ease of Use}

Similarly, Perceived Ease of Use in the context of Mobile Banking, assesses the extent to which Mobile Banking platforms, products or apps can be Perceived as user-friendly and free of effort by a user (Albashrawi and Motiwalla, 2017; Davis, 1989). Crucially, an IS that is fairly easy to use makes a user more willing to be knowledgeable about its features and subsequently intend to continue its use. Davis et al., (1989) also validated Perceived Ease of Use to have effect on Perceived Usefulness and has been empirically varied in many other different studies. The construct, again, has been validated in previous studies as a predictor of continuous usage intention both in other contexts like mobile internet(Hong et al., 2006) and e-government systems (Hamid et al., 2016), and Mobile Banking (Albashrawi \& Motiwalla, 2017). Hence, we hypothesize that:

H2a: Perceived Ease of Use is positively related to continuous usage intention

$\mathrm{H} 2 \mathrm{~b}$ : Perceived Ease of Use is positively related to Perceived Usefulness 


\section{Satisfaction}

Satisfaction, according to Albashrawi and Motiwalla (2017), refers to the degree at which an individual feels satisfied in using Mobile Banking services. Bhattacherjee (2001) empirically validated the role Satisfaction performs in impacting continuous intention. Existing literature further indicated Satisfaction as a major predictive factor that influences continuous intention of IS including web portal context (Lin et al., 2005), e-service (Hsu and Chiu, 2004), mobile internet (Hong et al., 2006), online shopping (Pappas et al., 2014), To this end, we hypothesize that:

H3: Satisfaction is positively related to continuous usage intention

\section{Perceived Innovativeness}

As the willingness of an individual to change and try out new technology, Agarwal and Prasad, (1998) validated Personal Innovativeness and realized its effect on Perceived Usefulness as well as Perceived Ease of Use in trying out new technology. Previous studies were able to provide evidence that there is a positive significant relationship between Personal Innovativeness and Perceived Ease of Use of mobile learning (Joo et al., 2014), mobile commerce (Lu, 2014), online check-in services (Lin and Filieri, 2015) and Mobile-based assessment (Nikou and Economides, 2017). Therefore, we propose the following hypothesis:

H4: Personal Innovativeness is positively related to Continuous usage intention

\section{Perceived Enjoyment}

Perceived Enjoyment reflects the extent to which individuals experience pleasure or joy as they interact with information technology. It is one of the core constructs that has been used to extend TAM in previous studies (Natarajan et al., 2018). Perceived Enjoyment as agreed in (Jusuf et al., 2017), is defined by Davis (1989) as how users are enjoying a technology. Kim (2010) puts it that Perceived Enjoyment which is an intrinsic motivation, plays a very critical role in enhancing/determining continuous intention of users of mobile data services. Numerous studies found Perceived Enjoyment to affect continuous intention (Choi et al., 2011; Gan and Li, 2018; Ifinedo, 2017; Kim, 2010). Kim (2010) indicated that Perceived Enjoyment has a positive impact on mobile data services continuous intention. Jusuf et al. (2017) establishes a significantly positive relationship between Perceived Enjoyment and Continuous Usage Intention of Mobile Banking. Perceived Enjoyment again relates to continuous usage intention in the context of mobile social apps (Hsiao, Chang, \& Tang, 2016). Researchers have integrated Perceived Enjoyment in different models including TAM (Hsu and Lu, 2007; Ifinedo, 2017) and ECM (Jusuf et al., 2017) and found significant positive relationship between Perceived Enjoyment and Continuous Usage Intention. Based on the explanations above, we hypothesize that:

H5: Perceived Enjoyment is positively related to continuous usage intention

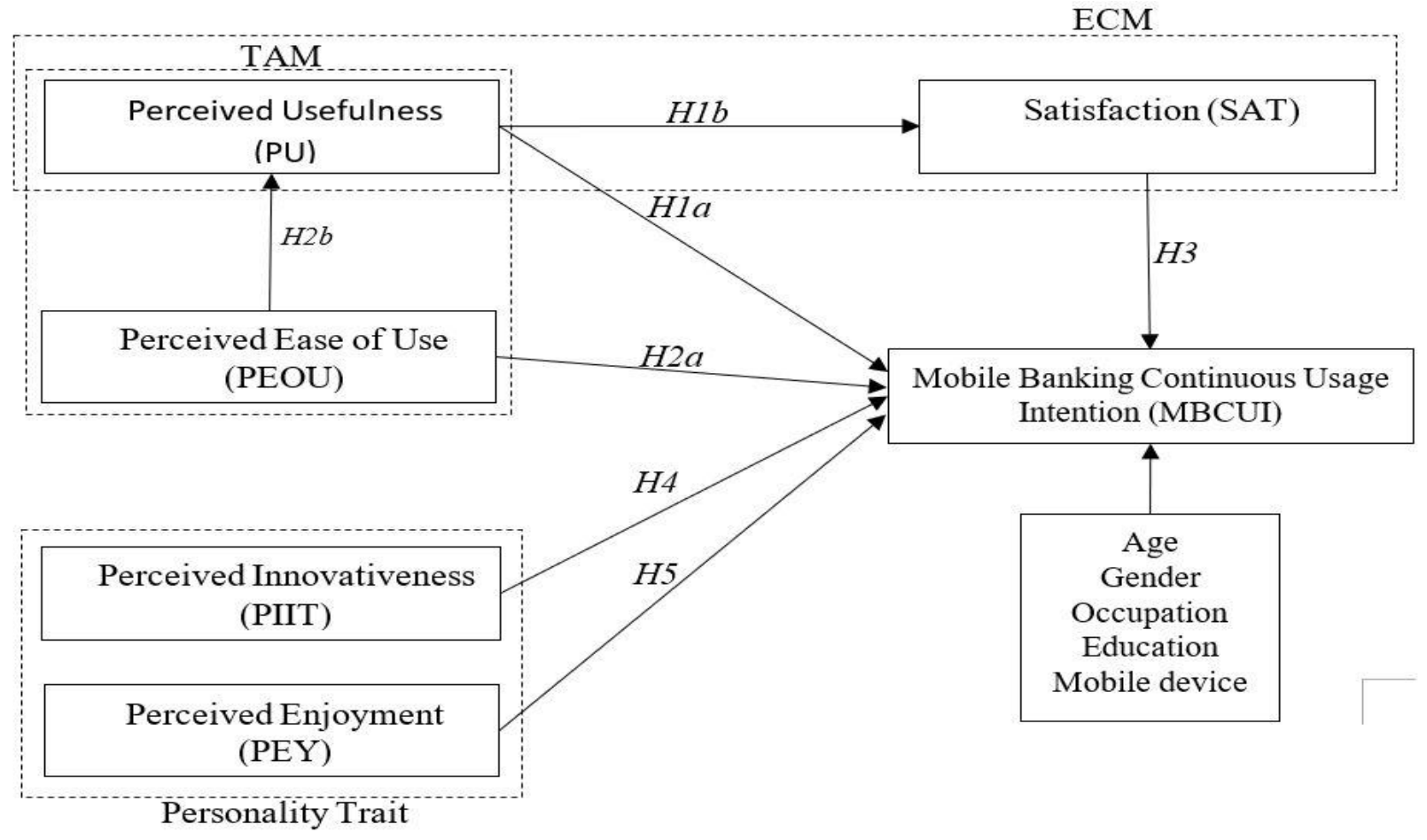

Figure 1: Research Model 


\section{Research Method}

\section{Data collection}

Research survey questionnaire was designed and randomly distributed to users of Mobile Banking in Tema and Kumasi, two of the fast-growing digital cities in Ghana. Tema and Kumasi are chosen for this study as the authors are familiar with these cities. The questionnaire was in English language since Ghana's official language is English so there was no need for back-translation method (Craig and Douglas, 2005). Preliminary questionnaire was made available to three other experts whose research area is in this field for their examination and suggestion. After effecting the comments and suggestions, the revised questionnaire was given to 10 students and 10 workers who are mobile banking users to pilot test. In addition, manual random collection of data approach was used for this study due to the fact that when online data collection approach was tested during the pretesting phase only 20 percent of feedback was received which was a convincing signal not to use online data collection survey approach. After pilot testing there was no need to make changes.

In view of this, 400 questionnaires were then distributed manually to respondents (in classrooms and downtown) and 295 were fully completed representing 73.8 percent of the total respondents. The demographics in table 1 , showed that respondents were largely male forming 58.6 percent while the rest are female. Majority of the respondents were between 20 and 29 years old forming 34.2 percent of the total respondents. Employees dominated the occupation category with 42 percent respondents while in terms of highest level of education, most of the respondents had bachelor degree forming 42.4 percent of total respondents. Non-degree holders such as those with at most high school diploma formed 31.2 percent of total mobile banking users. 9.8 percent had at least master's degree, 13.9 percent had qualifications less than diploma while 2.7 percent of the users did not indicate their level of education. Meanwhile, majority of the respondents (i.e., 84.1 percent) used mobile phone for mobile banking services. 7.5 percent used tablets for mobile banking while a fraction (3.4 percent) of the respondents used laptop. Meanwhile, 5 percent indicated other types of mobile devices such as smartwatch and PDA as the device used for mobile banking.

Table 1: Demographic information of respondents

\begin{tabular}{|l|l|l|l|}
\hline Demographics & & Frequency & $\begin{array}{l}\text { Percentage } \\
(\%)\end{array}$ \\
\hline \multirow{4}{*}{ Gender } & Male & 173 & 58.6 \\
\cline { 2 - 4 } & Female & 122 & 41.4 \\
\cline { 2 - 4 } & $\langle 20$ & 79 & 26.8 \\
\cline { 2 - 4 } & $20-29$ & 101 & 34.2 \\
\cline { 2 - 4 } & $30-39$ & 59 & 20 \\
\hline \multirow{5}{*}{ Occupation } & Student & 56 & 19 \\
\cline { 2 - 4 } & Employee & 107 & 36.3 \\
\cline { 2 - 4 } & Business owner or partner & 124 & 42 \\
\cline { 2 - 4 } & Unemployed & 25 & 8.5 \\
\cline { 2 - 4 } & Others & 30 & 10.2 \\
\hline \multirow{5}{*}{ Education } & Less than High School Diploma & 9 & 3 \\
\cline { 2 - 4 } & High School Diploma/Vocational & 41 & 13.9 \\
\cline { 2 - 4 } & Bachelor Degree & 92 & 31.2 \\
\cline { 2 - 4 } & Master Degree or Above & 125 & 42.4 \\
\cline { 2 - 4 } & Others & 29 & 9.8 \\
\hline Mobile Device & Mobile Phone & 8 & 2.7 \\
\cline { 2 - 4 } & Tablet & 248 & 84.1 \\
\cline { 2 - 4 } & Laptop & 22 & 3.5 \\
\cline { 2 - 4 } & Others & 10 & 5 \\
\hline
\end{tabular}

\section{Measures}

In line with the conceptual framework of the study all the constructs and the control variables are used for the evaluation. The constructs were all measured on a five-point Likert scale "strongly disagree" (1) to "strongly agree" (5). The measuring items were all adapted from previous studies and have been psychometrically validated. 
The measures for Perceived Usefulness were adapted from (F. D. \& R. B. Davis, 1989), measures for Perceived Ease of Use were adapted from (F. D. \& R. B. Davis, 1989), measures for Perceived Innovativeness were adapted from (Agarwal \& Prasad, 1998), measures for Perceived Enjoyment were adapted from (Jusuf et al., 2017), measures for Satisfaction were adapted from (Albashrawi \& Motiwalla, 2017) and measures for Mobile Banking Continuous Usage Intention were adapted from (Albashrawi \& Motiwalla, 2017; Bhattacherjee, 2001)

\section{Control variables}

The last section of the questionnaire contained the demographic questions where respondents were asked to provide information on gender, age, education, occupation and mobile device type which were considered as control variables in line with previous studies (Crabbe, Standing, Standing, \& Karjaluoto, 2009a; Aijaz A. Shaikh, Karjaluoto, \& Chinje, 2015a). Age was transformed to categories such that $1=$ under 20 years, $2=20-29$ years, $3=30-39$ years and, $4=40$ years and above. Gender was dichotomized where $0=$ male and $1=$ female. In terms of education, respondents were asked to choose an option from $1=$ junior high school to $5=$ others. They finally reported on both their occupation and the type of mobile device they use for mobile banking.

\section{Data Analysis}

Structural Equation Modeling (SEM) technique was employed to assess both the measurement model also known as Confirmatory Factor Analysis (CFA) and the structural model then tested the hypothesis (Anderson and Gerbing, 1988). SPSS Amos version 24 was used for the SEM technique. AMOS demands few requirements to verify a model and it's able to moderate relationships while also able to combine CFA and regression to estimate measurement model and structural model simultaneously (Anderson 2010 and 1998).

\section{Measurement model assessment}

First, to ensure the proposed model is fit, a CFA was performed and all the items variables have loadings greater than 0.7 (Nunnally and Bernstein, 1994). Hence, the CFA displayed acceptable model fit with statistical values; $\mathrm{X}^{2}=864.357, \mathrm{df}=355, \mathrm{p}<0.001, \mathrm{X}^{2} / \mathrm{df}=2.435$, Tucker-Lewis Index $(\mathrm{TLI})=.949$, Comparative Fit Index $(\mathrm{CFI})=.955$, Standardized Root Mean Residual $($ SRMR) $=.0358$, Root Mean Squared Error of Approximation $($ RMSEA) $=.049$ and PCLOSE=.626. Then, the following psychometric properties of the constructs are assessed; Convergent validity, Reliability and Discriminant validity. To establish the Convergent Validity, Nunnally and Bernstein (1994) stated that the values for each item loadings on their respective constructs need to be at least 0.7 and in addition, Fornell and Larcker (1981) indicated that the Average Variance Extracted (AVE) need to be higher than 0.5. The CFA results in this study showed that all the item loadings are above 0.7 and those for the AVE are greater than 0.5 which demonstrates that the respective constructs explain more than $50 \%$ of variance in each measure. Next, according to Nunnally and Bernstein (1994), Composite Reliability (CR) of more than 0.7 and Cronbach's alpha ( $\alpha$ ) higher than 0.7 are required to establish Reliability of the constructs. The constructs in this study satisfactorily showed CR between 0.823 and 0.920 , and $\alpha$ between 0.813 and 0.919 . Discriminant Validity is subsequently established when the square root of AVE for each construct is greater than all the other related inter-construct correlations (Fornell and Larcker, 1981). Since the square root of AVE (i.e. $(0.735 \leq \sqrt{ } A V E \leq 0.840)$ ) for each construct in this study is higher than all the other related inter-construct correlations as shown in table 3, the discriminant validity of the constructs is established.

Meanwhile, possible multicollinearity was assessed using variance inflation factor (VIF) and the scores for VIF are between 1.031 and 2.998 which are less than 3 or 10. Since Hair et al. (2010) recommended a threshold of 10 then this study has no issue with regards to multicollinearity. In addition, the threat of Common Method Bias (CMB) was assessed since only one individual was allowed to answer all questions in each survey questionnaire. To check the extent of CMB, Harman's single-factor test recommended in Podsakoff et al. (2003) is employed. CMB is high if just one factor explains more than $50 \%$ or majority of covariance in the variable. However, results showed among all the six factors, none in particular significantly dominate in explaining the covariances. Also, following the recommendation of Pavlou and Sawy (2006), exceptionally high correlations say $r>0.90$ among variables do not exist. Results show the inter-constructs correlations matrix intable 3 do not have unusually high values. Hence, CMB does not pose a significant threat to this study. Common Latent Factor (CLF) was introduced to the measurement model to test the possible common variances among the observed variables. Results show CLF impact on the observed variables was not significant and all the regression weights loaded high. Again, specific bias tests were conducted and results showed that the constrained and unconstrained models are the same i.e. they are invariant, an indication that no specific bias is detected to be affecting the model (Gaskin, J. and Lim, J. 2017). Therefore, CMB does not exist. 
Table 2: Results of reliability and CFA

\begin{tabular}{|c|c|c|c|c|c|c|c|c|c|}
\hline \multirow[t]{2}{*}{ Constructs } & \multirow[t]{2}{*}{ Items } & \multicolumn{6}{|c|}{ Standardized Factor loadings } & \multirow{2}{*}{$\begin{array}{l}\text { Cronbach } \\
\text { Alpha's } \\
(\alpha)\end{array}$} & \multirow{2}{*}{$\begin{array}{l}\text { Composite } \\
\text { reliability } \\
(\mathrm{CR})\end{array}$} \\
\hline & & 1 & 2 & 3 & 4 & 5 & 6 & & \\
\hline \multirow{5}{*}{$\begin{array}{l}\text { Perceived } \\
\text { Usefulness } \\
\text { (PUF) }\end{array}$} & PUF2 & 0.892 & & & & & & \multirow{5}{*}{0.919} & \multirow{5}{*}{0.920} \\
\hline & PUF3 & 0.879 & & & & & & & \\
\hline & PUF4 & 0.862 & & & & & & & \\
\hline & PUF1 & 0.832 & & & & & & & \\
\hline & PUF5 & 0.634 & & & & & & & \\
\hline \multirow{6}{*}{$\begin{array}{l}\text { Perceived } \\
\text { Enjoyment } \\
\text { (PEY) }\end{array}$} & PEY4 & & 0.850 & & & & & \multirow{6}{*}{0.896} & \multirow{6}{*}{0.897} \\
\hline & PEY7 & & 0.825 & & & & & & \\
\hline & PEY5 & & 0.802 & & & & & & \\
\hline & PEY3 & & 0.732 & & & & & & \\
\hline & PEY2 & & 0.679 & & & & & & \\
\hline & PEY6 & & 0.638 & & & & & & \\
\hline \multirow{6}{*}{$\begin{array}{l}\text { Mobile } \\
\text { Banking } \\
\text { Continuous } \\
\text { Usage Intention } \\
\text { (MBCUI) }\end{array}$} & MBCUI1 & & & 0.879 & & & & \multirow{6}{*}{0.898} & \multirow{6}{*}{0.894} \\
\hline & MBCUI2 & & & 0.837 & & & & & \\
\hline & MBCUI3 & & & 0.811 & & & & & \\
\hline & MBCUI5 & & & 0.708 & & & & & \\
\hline & MBCUI6 & & & 0.688 & & & & & \\
\hline & MBCUI4 & & & 0.606 & & & & & \\
\hline \multirow[t]{4}{*}{$\begin{array}{l}\text { Satisfaction } \\
\text { (SAT) }\end{array}$} & SAT3 & & & & 0.952 & & & \multirow{4}{*}{0.872} & \multirow{4}{*}{0.875} \\
\hline & SAT4 & & & & 0.835 & & & & \\
\hline & SAT2 & & & & 0.657 & & & & \\
\hline & SAT1 & & & & 0.642 & & & & \\
\hline \multirow{4}{*}{$\begin{array}{l}\text { Personal } \\
\text { Innovativeness } \\
\text { (PIIT) }\end{array}$} & PIIT1 & & & & & 0.928 & & \multirow{4}{*}{0.813} & \multirow{4}{*}{0.823} \\
\hline & PIIT4 & & & & & 0.710 & & & \\
\hline & PIIT3 & & & & & 0.631 & & & \\
\hline & PIIT2 & & & & & 0.551 & & & \\
\hline \multirow[t]{4}{*}{$\begin{array}{l}\text { Perceived Ease } \\
\text { of Use (PEOU) }\end{array}$} & PEOU2 & & & & & & 0.859 & \multirow{4}{*}{0.903} & \multirow{4}{*}{0.905} \\
\hline & PEOU3 & & & & & & 0.847 & & \\
\hline & PEOU1 & & & & & & 0.735 & & \\
\hline & PEOU4 & & & & & & 0.571 & & \\
\hline
\end{tabular}

Table 3 discriminant validity and inter-correlations of constructs

\begin{tabular}{|l|r|r|r|l|l|l|l|r|r|}
\hline & \multicolumn{1}{|c|}{ AVE } & \multicolumn{1}{|c|}{ MSV } & MaxR(H) & PU & PEY & MBCUI & SAT & PIIT & PEOU \\
\hline PU & .699 & .590 & .924 & $\mathbf{0 . 8 3 6}$ & & & & & \\
\hline PEY & .594 & .407 & .902 & $.439^{* * *}$ & $\mathbf{. 7 7 0}$ & & & & \\
\hline MBCUI & .586 & .407 & .902 & $.533^{* * *}$ & $.638^{* * *}$ & $\mathbf{. 7 6 6}$ & & & \\
\hline SAT & .639 & .419 & .895 & $.206^{* * *}$ & $.109^{*}$ & $.194^{* * *}$ & $\mathbf{. 8 0 0}$ & & \\
\hline PIIT & .541 & .419 & .853 & $.286^{* * *}$ & $.256^{* * *}$ & $.279^{* * *}$ & $.647 * * *$ & $\mathbf{. 7 3 5}$ & \\
\hline PEOU & .705 & .590 & .911 & $.768^{* * *}$ & $.441^{* * *}$ & $.475^{* * *}$ & $.165 * * *$ & $.251^{* * *}$ & $\mathbf{. 8 4 0}$ \\
\hline
\end{tabular}

$* * * \mathrm{p}<.001,{ }^{* *} \mathrm{p}<.01,{ }^{*} \mathrm{p}<.05, \dagger \mathrm{p}<.10$ 


\section{Structural model}

\begin{tabular}{|l|c|c|c|}
\hline \multicolumn{5}{|c|}{ Fit indices for measurement and structural models } \\
\hline Fit index & Measurement model & Structural model & Guidelines \\
\hline $\mathrm{X}^{2}$ & 864.357 & 62.686 & \\
\hline $\mathrm{Df}$ & 355 & 26 & \\
\hline $\mathrm{X}^{2} / \mathrm{df}$ & 2.435 & 2.411 & $<3$ \\
\hline TLI & .949 & .969 & $>0.9$ \\
\hline NFI & .927 & .970 & $>0.9$ \\
\hline CFI & .955 & .982 & $>0.9$ \\
\hline SRMR & .0358 & .0305 & $<0.05$ \\
\hline RMSEA & .049 & .049 & $<0.08$ \\
\hline PCLOSE & .626 & .528 & $>.1$ \\
\hline
\end{tabular}

\section{Hypothesis testing}

\begin{tabular}{|l|l|l|l|}
\hline Hypothesis & Relationship & $\begin{array}{l}\text { Path } \\
\text { coefficients } \\
\text { (Standardized) }\end{array}$ & $\begin{array}{l}\text { Result of } \\
\text { hypothesis testing }\end{array}$ \\
\hline H1a & $\begin{array}{l}\text { Perceived Usefulness } \rightarrow \text { Mobile Banking Continuous } \\
\text { Usage Intention }\end{array}$ & .299 & Supported \\
\hline H1b & Perceived Usefulness $\rightarrow$ Satisfaction & .134 & Supported \\
\hline H2a & $\begin{array}{l}\text { Perceived Ease of Use } \rightarrow \text { Mobile Banking Continuous } \\
\text { Usage Intention }\end{array}$ & .001 & Not supported \\
\hline H2b & Perceived Ease of Use $\rightarrow$ Perceived Usefulness & .817 & Supported \\
\hline H3 & Satisfaction $\rightarrow$ Mobile Banking Continuous Usage Intention & .072 & Supported \\
\hline H4 & $\begin{array}{l}\text { Personal Innovativeness } \rightarrow \text { Mobile Banking Continuous } \\
\text { Usage Intention }\end{array}$ & .016 & Not supported \\
\hline H5 & $\begin{array}{l}\text { Perceived Enjoyment } \rightarrow \text { Mobile Banking Continuous Usage } \\
\text { Intention }\end{array}$ & .545 & Supported \\
\hline
\end{tabular}

ECM

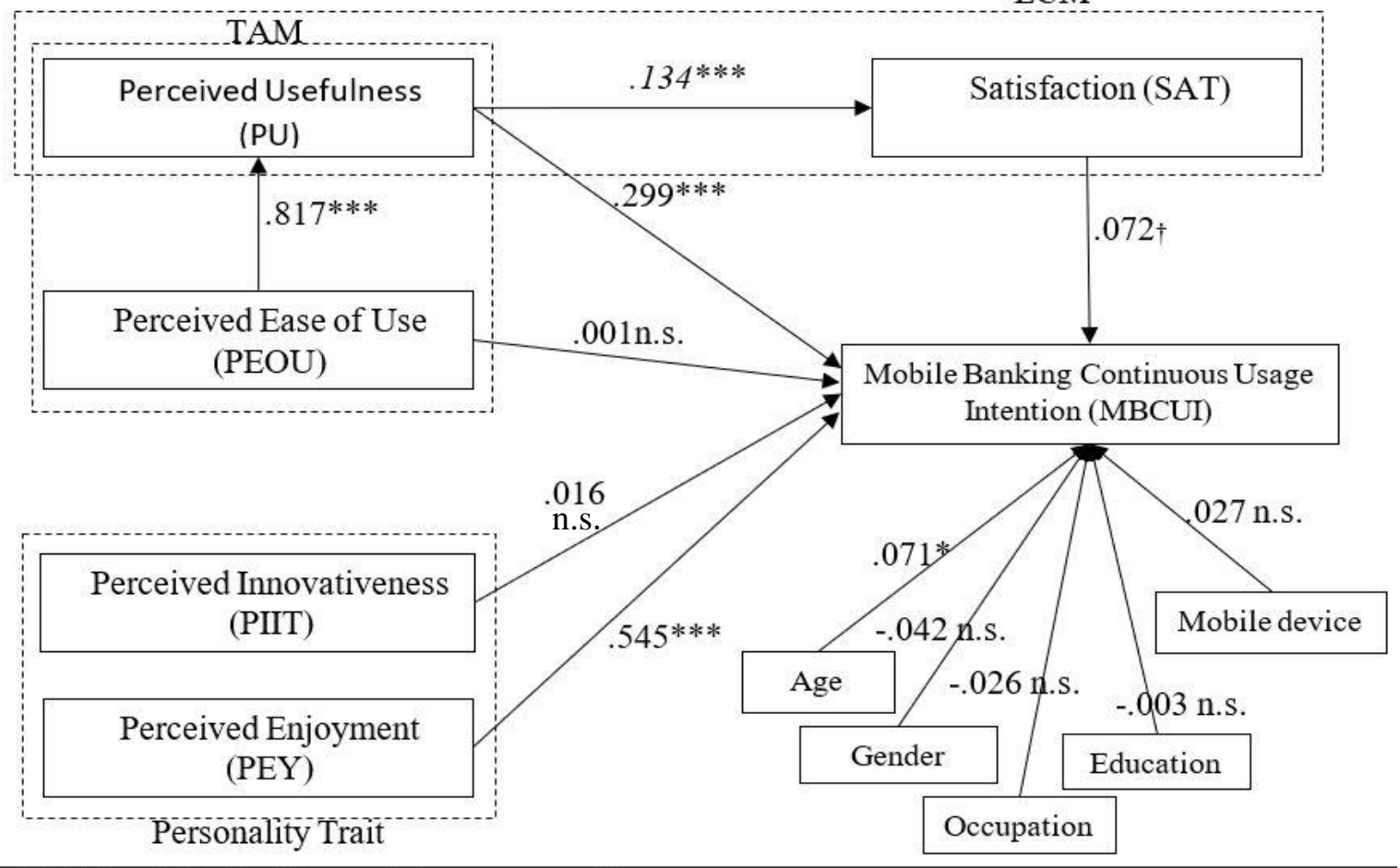

$*^{* *} p<.001 ; * * p<.010 ; * p<.05 ; \dagger p<.10 ;$ n.s.=not significant

Figure 2: Research model results 


\section{Results and Discussion}

This research draws on TAM and ECM theories to elucidate the mechanisms linking some antecedents of IS acceptance and IS continuous usage intention to ascertain the coexistence of these antecedents in predicting Mobile Banking Continuous Usage Intention. In addition, personality traits have been expatiated to find their interplay effects on Mobile Banking Continuous Usage Intention by supporting the two categories of antecedents (i.e., antecedents of acceptance from the dimensions of TAM and those from IS continuous usage intention from the dimensions of ECM). Results in Figure 2 showed that the antecedents of IS acceptance particularly Perceived Ease of Use does not have enough statistical support to predict Mobile Banking Continuous Usage Intention ( $\beta=.001$, n.s.). This outcome is in line with previous studies on IS continuous usage intention which found that antecedents of IS acceptance are not able to predict IS continuous intention since the context are different. However, Perceived Ease of Use significantly predicts Perceived Usefulness $(\beta=.817, \mathrm{p}<.001)$. Meanwhile, Perceived Usefulness with its extensive scope of influence significantly predict both Mobile Banking Continuous Usage Intention $(\beta=.229, p<.001)$ and Satisfaction $(\beta=.134$, $\mathrm{p}<.001$ ). Furthermore, Satisfaction had positive and significant relationship with Mobile Banking Continuous Usage Intention $(\beta=.072, p<.10)$. In terms of personality traits, Perceived Enjoyment had profound effect on positively influencing Mobile Banking Continuous Usage Intention $(\beta=.545, \mathrm{p}<.001)$. This result is in accordance with prior studies that found the importance of personality traits in impacting on users' Mobile Banking Continuous Usage Intention. Meanwhile, the relationship between Perceived Innovativeness and Mobile Banking Continuous Usage Intention is not significant $(\beta=.016, \mathrm{n} . \mathrm{s})$. Perhaps, this could be attributed to the fact that users of mobile banking are unable to associate their innovativeness to helping them to continuously form intention to use mobile banking.

Among the possible covariate effects, the age of users has significant positive effect on their Mobile Banking Continuous Usage Intention $(\beta=.071, \mathrm{p}<.05)$. This result is in accordance with earlier studies that found age of mobile banking users to influence their continuous usage of mobile banking. On the other hand, other control variables did not have any possible confounding effect on Mobile Banking Continuous Usage Intention.

\section{Conclusions}

\section{Conclusion}

This research aimed to extend our understanding regarding the coexistence of antecedents of adoption of mobile banking and antecedents of Mobile Banking Continuous Usage Intention through the integration of some dimensions of TAM and ECM models and supporting the integration with some personality trait factors. Analysis of survey data from respondents yielded significant findings that support five of the research hypotheses. An indication that, personality trait and antecedents of continuous usage intention of IS are suitable in determining Mobile Banking Continuous Usage Intention while antecedents of adoption need not necessarily be applied in the context of continuous usage intention.

\section{Theoretical Implication}

This study is among one of the earliest works we know to adapt TAM and ECM theory in the setting of Mobile Banking Continuous Usage Intention to ascertain the coexistence of the dimensions in these theories to determine Mobile Banking Continuous Usage Intention. Using the TAM and ECM theory, the present study enhanced the understanding of five antecedents of mobile banking adoption and continuous intention and developed hypotheses to test their direct influence on Mobile Banking Continuous Usage Intention. Although, it's worthwhile to note that, the antecedents of adoption from TAM and the antecedents of continuous intention from ECM theory functions better when they are separately used in the context of adoption and continuous intention respectively. This paper also unraveled the importance of personality traits in supporting the various determinants of adoption and continuous intention of IS in predicting users' continuous behavioral intention of IS.

Additionally, the examination asserts that Perceived Usefulness is positively related to Satisfaction while Satisfaction further predict Mobile Banking Continuous Usage Intention. This assertion has been supported by a significant number of studies in the field of mobile banking. Revealing that, these two predictors are still salient in research on determining Mobile Banking Continuous Usage Intention for that matter IS in general.

\section{Practical implication}

The findings also have practical implication for mobile banking providers. Practically, Perceived Usefulness is found to positively influence Mobile Banking Continuous Usage Intention. This calls for mobile banking providers particularly banks to enhance mobile banking in order to let users be able perform varieties of task when using mobile banking. Similarly, Satisfaction of users significantly impacts on Mobile Banking Continuous Usage Intention of users. This also calls for banks to ensure mobile banking provide services that give users the feeling of good experience in the course of using mobile banking. In that, satisfied customers are more likely to continue using Mobile Banking service. 
Furthermore, as customers enjoy the continuous usage of mobile banking service, it serves as motivation to bankers and developers of mobile banking services to continue with innovation services and provide constant update to enhance and promote better services.

\section{Limitation and future research directions}

This study only focused on two cities located in Ghana. To ensure the findings are generalized, it is necessary for future studies to test the research model in other cities or countries. The study attempted to examine determinants in the context of mobile banking in Ghana. However, only some selected variables were considered for the study due to limited time and study context which could limit some important relationships such as those between antecedents of adoption and personality traits. In addition, other many personality traits exist and also the confirmation stage of ECM were not considered in this study.

Future study can delve into other antecedents to enhance the understanding of the antecedents of Mobile Banking Continuous Usage Intention. Furthermore, future research could separate the TAM and ECM theoretical models for assessing adoption and continuous intention respectively as the context are different. However, personality traits can be applied in both contexts to give a comprehensive account on how the antecedents in conjunction with personality traits determine either adoption or continuous usage intention of IS.

This paper serves as a guide or base for further research work to be carried out in understanding the antecedents of Mobile Banking Continuous Usage Intention. It is also important to be cautious in the application of the model since different samples and other variables may present different results. Lastly, the respondents were recruited from local communities with majority between the ages of 20 and 29. Most of them are well educated with bachelor's degree and above. Future studies could recruit more participants from different age brackets and from different educational background.

\section{Acknowledgment}

First of all, our thanks go to Almighty God for His abundance blessings during the course of this research till its successful end. A very special gratitude goes to Prof. Fang Jiaming support and mentorship throughout this research work. Our appreciation also goes to the funding support of National Natural Science Foundation of China under grant number, 71571029.

\section{References}

Adapa, S., \& Roy, S. K. (2017). Consumers' post-adoption behaviour towards Internet banking: empirical evidence from Australia. Behaviour and Information Technology, 36(9), 970-983. https://doi.org/10.1080/0144929X.2017.1319498

Afshan, S., \& Sharif, A. (2016). Acceptance of mobile banking framework in Pakistan. Telematics and Informatics, 33(2), 370-387. https://doi.org/10.1016/j.tele.2015.09.005

Agarwal, R., \& Prasad, J. (1998). A Conceptual and Operational Definition of Personal Innovativeness in the Domain of Information Technology. Information Systems Research, 9(2), 204-215. https://doi.org/10.1287/isre.9.2.204

Al-Ghazali, B. M., Md Rasli, A., Md Yusoff, R., \& Mutahar, A. Y. (2015). Antecedents of Continuous Usage Intention of Mobile Banking Services from The Perspective of DeLone and McLean Model of Information System Success. International Journal of Economics and Financial Issues, 5, 13-21.

Albashrawi, M., \& Motiwalla, L. (2017). Privacy and Personalization in Continued Usage Intention of Mobile Banking: An Integrative Perspective. Information Systems Frontiers, 1-13. https://doi.org/10.1007/s10796-017-9814-7

Aldás-Manzano, J., Ruiz-Mafé, C., \& Sanz-Blas, S. (2009). Exploring individual personality factors as drivers of M-shopping acceptance. Industrial Management \& Data Systems, 109(6), 739-757. https://doi.org/10.1108/02635570910968018

Amin, H., Supinah, R., Aris, M. M., \& Baba, R. (2012). Receptiveness of mobile banking by Malaysian local customers in Sabah: An empirical investigation. Journal of Internet Banking and Commerce, 15(1), 1-11. https://doi.org/10.1007/978-3-531-92534-9_12

Anderson, J. C., \& Gerbing, D. W. (1988). Structural Equation Modeling in Practice: A Review and Recommended TwoStep Approach. Psychological Bulletin, 103(3), 411-423. https://doi.org/10.1037/0033-2909.103.3.411

Arahita, C. L., \& Hatammimi, J. (2015). Factors Affecting the Intention to Reuse Mobile Banking Service. International Journal of Research in Business and Social Science (2147-4478), 4(4), 15. https://doi.org/10.20525/ijrbs.v4i4.15

Arcand, M., PromTep, S., Brun, I., \& Rajaobelina, L. (2017). Mobile banking service quality and customer relationships. International Journal of Bank Marketing, 35(7), 1066-1087. https://doi.org/10.1108/IJBM-10-2015-0150 
Baptista, G., \& Oliveira, T. (2017). Why so serious? Gamification impact in the acceptance of mobile banking services. Internet Research, 27(1), 118-139. https://doi.org/10.1108/IntR-10-2015-0295

Barnes, S. J., \& Corbitt, B. (2003). Mobile banking: concept and potential. International Journal of Mobile Communications, 1(3), 273. https://doi.org/10.1504/IJMC.2003.003494

Berraies, S., Yahia, K. Ben, \& Hannachi, M. (2017). Identifying the effects of perceived values of mobile banking applications on customers Comparative study between baby boomers, generation $\mathrm{X}$ and generation $\mathrm{Y}$. International Journal of Bank Marketing, 35(6), 1018-1038. https://doi.org/10.1108/IJBM-09-2016-0137

Bhattacherjee, A. (2001). Understanding Information Systems Continuance: An Expectation-Confirmation Model 2001b. MIS Quarterly, 25(3), 351. https://doi.org/10.2307/3250921

Boakye, K. G., Prybutok, V. R., \& Ryan, S. D. (2012). The intention of continued web-enabled phone service usage: A quality perspective. Operations Management Research, 5(1-2), 14-24. https://doi.org/10.1007/s12063-012-0062-1

BOG, B.-G. (2017). Payment Systems Oversight Annual Report, 2017. Bank of Ghana Reports. Retrieved from https://www.bog.gov.gh/privatecontent/Payment Systems/Payment Systems Annual Report 2017.pdf

Choi, H., Kim, Y., \& Kim, J. (2011). Driving factors of post adoption behavior in mobile data services. Journal of Business Research, 64(11), 1212-1217. https://doi.org/10.1016/j.jbusres.2011.06.025

Chou, S. W., Lee, C. C., Chang, Y. C., \& Lin, C. T. (2009). Understanding continuance intention of knowledge creation in online communities from a social-psychological perspective. Proceedings of the 42nd Annual Hawaii International Conference on System Sciences, HICSS, 1-10. https://doi.org/10.1109/HICSS.2009.476

Crabbe, M., Standing, C., Standing, S., \& Karjaluoto, H. (2009a). An adoption model for mobile banking in Ghana. International Journal of Mobile Communications, 7(5), 515-543. https://doi.org/10.1504/IJMC.2009.024391

Crabbe, M., Standing, C., Standing, S., \& Karjaluoto, H. (2009b). An adoption model for mobile banking in Ghana Margaret Crabbe, Craig Standing * and Susan Standing Heikki Karjaluoto. International Journal of Mobile Communications, 7(5), 515-543.

Cudjoe, A. G., Anim, P. A., \& Tetteh Nyanyofio, J. G. N. (2015). Determinants of Mobile Banking Adoption in the Ghanaian Banking Industry: A Case of Access Bank Ghana Limited. Journal of Computer and Communications, 03(02), 1-19. https://doi.org/10.4236/jcc.2015.32001

Danquah, M., \& Iddrisu, A. M. (2018). Access to mobile phones and the wellbeing of non-farm enterprise households: Evidence from Ghana. Technology in Society. https://doi.org/10.1016/j.techsoc.2018.01.012

Davis, F. D. (1986). A technology acceptance model for empirically testing new end-user information systems: theory and results. Sloan School of Management Massachusetts Institute of Technology.

Davis, F. D. (1989). Perceived Usefulness, Perceived Ease of Use , and User Acceptance of Information Technology. MIS Quarterly, 13(3), 319. https://doi.org/10.2307/249008

Davis, F. D. \& R. B. (1989). User Acceptance of Computer Technology: A Comparison of Two Theoretical Models, (August). https://doi.org/10.1287/mnsc.35.8.982

Davis, F. D., Bagozzi, R. P., \& Warshaw, P. R. (1989). User Acceptance of Computer Technology : a Comparison of Two Theoretical Models *, 35(8).

Davis, F. D., Bagozzi, R. P., \& Warshaw, P. R. (1992). Extrinsic and Intrinsic Motivation to Use Computers in the Workplace. Journal of Applied Social Psychology, 22(14), 1111-1132. https://doi.org/10.1111/j.1559-1816.1992.tb00945.x

Deci, E. L., \& Ryan, R. M. (2000). The "What" and "Why" of Goal Pursuits: Human Needs and the Self-Determination of Behavior. ZEV Rail Glasers Annalen, 11(4), 227-268. https://doi.org/10.1207/S15327965PLI1104

Dineshwar, R., \& Steven, M. (2013). An Investigation on Mobile Banking Adoption and Usage: A Case Study of Mauritius. Proceedings of 3rd Asia-Pacific Business Research Conference, 3(February), 1-21.

Farah, M. F., Hasni, M. J. S., \& Abbas, A. K. (2018). Mobile-banking adoption: empirical evidence from the banking sector in Pakistan. International Journal of Bank Marketing, 36(7), 1386-1413. https://doi.org/10.1108/IJBM-10-20170215

Fishbein, M., \& Ajzen, I. (1975). Belief, Attitude, Intention, and Behavior: An Introduction to Theory and Research. Reading, MA: Addison-Wesley. https://doi.org/10.1017/CBO9781107415324.004

Gallego, M. D., Bueno, S., \& Noyes, J. (2016). Second Life adoption in education: A motivational model based on Uses and Gratifications theory. Computers and Education, 100, 81-93. https://doi.org/10.1016/j.compedu.2016.05.001

Gan, C., \& Li, H. (2018). Understanding the effects of gratifications on the continuance intention to use WeChat in China: A perspective on uses and gratifications. Computers in Human Behavior, 78, 306-315. https://doi.org/10.1016/j.chb.2017.10.003

Gefen, D., \& Straub, D. (2003). Managing User Trust in B2C e-Services. E-Service Journal, 2(2), 7-24. https://doi.org/10.2979/ESJ.2003.2.2.7

Gu, J. C., Lee, S. C., \& Suh, Y. H. (2009). Determinants of behavioral intention to mobile banking. Expert Systems with Applications, 36(9), 11605-11616. https://doi.org/10.1016/j.eswa.2009.03.024 
Gu, R., Jiang, Z. J., Oh, L.-B., \& Wang, K. (2018). Exploring the impact of optimum stimulation level on individual perceptions of IT innovations: A trait hierarchical model perspective. Data Base for Advances in Information Systems, 49(1), 67-91. https://doi.org/10.1145/3184444.3184450

Gumussoy, C. A. (2016). Factors affecting users' decision to continue using mobile banking in Turkey. International Journal of Mobile Communications, 14(4), 411. https://doi.org/10.1504/IJMC.2016.077341

Hamid, A. A., Razak, F. Z. A., Bakar, A. A., \& Abdullah, W. S. W. (2016). The Effects of Perceived Usefulness and Perceived Ease of Use on Continuance Intention to Use E-Government. Procedia Economics and Finance, 35(October 2015), 644-649. https://doi.org/10.1016/S2212-5671(16)00079-4

Hanafizadeh, P., Behboudi, M., Abedini Koshksaray, A., \& Jalilvand Shirkhani Tabar, M. (2014). Mobile-banking adoption by Iranian bank clients. Telematics and Informatics, 31(1), 62-78. https://doi.org/10.1016/j.tele.2012.11.001

Holden, R. J., \& Karsh, B. T. (2010). The Technology Acceptance Model: Its past and its future in health care. Journal of Biomedical Informatics, 43(1), 159-172. https://doi.org/10.1016/j.jbi.2009.07.002

Hong, J. C., Lin, P. H., \& Hsieh, P. C. (2016). The effect of consumer innovativeness on perceived value and continuance intention to use smartwatch. Computers in Human Behavior, 67, 264-272. https://doi.org/10.1016/j.chb.2016.11.001

Hong, S. J., Thong, J. Y. L., \& Tam, K. Y. (2006). Understanding continued information technology usage behavior: A comparison of three models in the context of mobile internet. Decision Support Systems, 42(3), 1819-1834. https://doi.org/10.1016/j.dss.2006.03.009

Hsiao, C. H., Chang, J. J., \& Tang, K. Y. (2016). Exploring the influential factors in continuance usage of mobile social Apps: Satisfaction, habit, and customer value perspectives. Telematics and Informatics, 33(2), 342-355. https://doi.org/10.1016/j.tele.2015.08.014

Hsu, C. L., \& Lu, H. P. (2007). Consumer behavior in online game communities: A motivational factor perspective. Computers in Human Behavior, 23(3), 1642-1659. https://doi.org/10.1016/j.chb.2005.09.001

Hsu, M. H., \& Chiu, C. M. (2004). Predicting electronic service continuance with a decomposed theory of planned behaviour. Behaviour and Information Technology, 23(5), 359-373. https://doi.org/10.1080/01449290410001669969

Iddris, F. (2013). Barriers to Adoption of Mobile banking: Evidence from Ghana. International Journal of Academic Research in Business and Social Sciences, 3(7). https://doi.org/10.6007/IJARBSS/v3-i7/59

Ifinedo, P. (2017). Examining students' intention to continue using blogs for learning: Perspectives from technology acceptance, motivational, and social-cognitive frameworks. Computers in Human Behavior, 72, 189-199. https://doi.org/10.1016/j.chb.2016.12.049

Jamshidi, D., Keshavarz, Y., Kazemi, F., \& Mohammadian, M. (2018). Mobile banking behavior and flow experience. International Journal of Social Economics, 45(1), 57-81. https://doi.org/10.1108/IJSE-10-2016-0283

Joo, Y. J., Lee, H. W., \& Ham, Y. (2014). Integrating user interface and Personal Innovativeness into the TAM for mobile learning in Cyber University. Journal of Computing in Higher Education, 26(2), 143-158. https://doi.org/10.1007/s12528-014-9081-2

Jusuf, M. B., Utami, N. P., Hidayanto, A. N., \& Shihab, M. R. (2017). Analysis of Intrinsic Factors of Mobile Banking Application Users ' Continuance Intention An Evaluation Using an Extended Expectation Confirmation Model.

Kim, B. (2010). An empirical investigation of mobile data service continuance: Incorporating the theory of planned behavior into the expectation-confirmation model. Expert Systems with Applications, 37(10), 7033-7039. https://doi.org/10.1016/j.eswa.2010.03.015

Kim, M. J., Kim, W. G., \& Kim, J. M. K. and C. (2016). Does knowledge matter to seniors' usage of mobile devices? Focusing on motivation and attachment. Journal of Managerial Psychology, Vol. 28(8), 1702-1727. https://doi.org/http://dx.doi.org/10.1108/02683940010305270

Laukkanen, T. (2016). Consumer adoption versus rejection decisions in seemingly similar service innovations: The case of the Internet and mobile banking. Journal of Business Research, 69(7), 2432-2439. https://doi.org/10.1016/j.jbusres.2016.01.013

Li, H., \& Liu, Y. (2014). Understanding post-adoption behaviors of e-service users in the context of online travel services. Information and Management, 51(8), 1043-1052. https://doi.org/10.1016/j.im.2014.07.004

Lin, C. S., Wu, S., \& Tsai, R. J. (2005). Integrating perceived playfulness into expectation-confirmation model for web portal context. Information and Management, 42(5), 683-693. https://doi.org/10.1016/j.im.2004.04.003

Lin, H. F. (2011). An empirical investigation of mobile banking adoption: The effect of innovation attributes and knowledgebased trust. International Journal of Information Management, 31(3), 252-260. https://doi.org/10.1016/j.ijinfomgt.2010.07.006

Lin, W. S., \& Wang, C. H. (2012). Antecedences to continued intentions of adopting e-learning system in blended learning instruction: A contingency framework based on models of information system success and task-technology fit. Computers and Education, 58(1), 88-99. https://doi.org/10.1016/j.compedu.2011.07.008 
Lin, Z., \& Filieri, R. (2015). Airline passengers' continuance intention towards online check-in services: The role of Personal Innovativeness and subjective knowledge. Transportation Research Part E: Logistics and Transportation Review, 81, 158-168. https://doi.org/10.1016/j.tre.2015.07.001

Liu, Y., Li, H., \& Carlsson, C. (2010). Factors driving the adoption of m-learning: An empirical study. Computers and Education, 55(3), 1211-1219. https://doi.org/10.1016/j.compedu.2010.05.018

Liu, Z., Min, Q., \& Ji, S. (2009). An Empirical Study on Mobile Banking Adoption: The Role of Trust. 2009 Second International Symposium on Electronic Commerce and Security, 7-13. https://doi.org/10.1109/ISECS.2009.150

Lu, J. (2014). Are Personal Innovativeness and social influence critical to continue with mobile commerce? Internet Research, 24(2), 134-159. https://doi.org/10.1108/IntR-05-2012-0100

Luarn, P., \& Lin, H. H. (2005). Toward an understanding of the behavioral intention to use mobile banking. Computers in Human Behavior, 21(6), 873-891. https://doi.org/10.1016/j.chb.2004.03.003

Mahatanankoon, P. (2007). The Effects of Personality Traits and Optimum Stimulation Level on Text-Messaging Activities and M-commerce Intention. International Journal of Electronic Commerce, 12(1), 7-30. https://doi.org/10.2753/JEC1086-4415120101

MHA, K. (2015). A mobile banking adoption model in the Jordanian market: An integration of TAM with perceived risks and perceived benefits. Journal of Internet Banking and Commerce, 20(3). https://doi.org/10.4172/2165-7866.1000128

Mohammadi, H. (2015). A study of mobile banking loyalty in Iran 2015a. Computers in Human Behavior, 44 , 35-47. https://doi.org/10.1016/j.chb.2014.11.015

Muhammad Al Amine, M. A. B. (2016). Islamic Finance and Africa’s Economic Resurgence. https://doi.org/10.1007/978-3-319-28835-2

Natarajan, T., Balasubramanian, S. A., \& Kasilingam, D. L. (2018). The moderating role of device type and age of users on the intention to use mobile shopping applications. Technology in Society, 53, 79-90. https://doi.org/10.1016/j.techsoc.2018.01.003

Nikou, S. A., \& Economides, A. A. (2017). Mobile-based assessment: Investigating the factors that influence behavioral intention to use. Computers and Education, 109, 56-73. https://doi.org/10.1016/j.compedu.2017.02.005

Owusu Kwateng, K., Osei Atiemo, K. A., \& Appiah, C. (2018). Acceptance and use of mobile banking: an application of UTAUT2. Journal of Enterprise Information Management. https://doi.org/10.1108/JEIM-03-2018-0055

Pappas, I. O., Pateli, A. G., Giannakos, M. N., \& Chrissikopoulos, V. (2014). Moderating effects of online shopping experience on customer Satisfaction and repurchase intentions. International Journal of Retail and Distribution Management, 42(3), 187-204. https://doi.org/10.1108/IJRDM-03-2012-0034

Reji kumar, G., \& Sudharani, R. D. (2012). An Empirical Study on Service Quality Perceptions and Continuance Intention in Mobile Banking context in India. Journal of Internet Banking and Commerce, 17(1), 1-22.

Rogers, E. M. (1995). Diffusion of innovations. Macmillian Publishing Co. https://doi.org/citeulike-article-id:126680

Safeena, Rahmath; Date, Hema;Kammani, Abdullaj; Hundewale, N. (2012). Technology Adoption and Indian Consumers: Study on Mobile Banking. International Journal of Computer Theory and Engineering, 4(6), 1020-1024. https://doi.org/10.7763/IJCTE.2012.V4.630

Schillewaert, N., Ahearne, M. J., Frambach, R. T., \& Moenaert, R. K. (2005). The adoption of information technology in the sales force. Industrial Marketing Management, 34(4 SPEC ISS.), 323-336. https://doi.org/10.1016/j.indmarman.2004.09.013

Scornavacca, E., \& Barnes, S. J. (2004). M-banking services in Japan: A strategic perspective. International Journal of Mobile Communications, 2(1), 51-66. https://doi.org/10.1504/IJMC.2004.004487

Scornavacca, E., \& Hoehle, H. (2007). Mobile banking in Germany: a strategic perspective. International Journal of Electronic Finance, 1(3), 304. https://doi.org/10.1504/IJEF.2007.011501

Shaikh, A. (2016). Examining consumers' intention, behavior, and beliefs in mobile banking adoption and continuous usage. Jyväskylä studies in business and economics 172. Retrieved from https://jyx.jyu.fi/dspace/handle/123456789/52389

Shaikh, A. A., \& Karjaluoto, H. (2014). Mobile banking adoption: A literature review. Telematics and Informatics, 32(1), 129-142. https://doi.org/10.1016/j.tele.2014.05.003

Shaikh, A. A., \& Karjaluoto, H. (2015). Mobile banking adoption: A literature review. Telematics and Informatics, 32(1), 129-142. https://doi.org/http://dx.doi.org/10.1016/j.tele.2014.05.003

Shaikh, A. A., \& Karjaluoto, H. (2016). Mobile Banking Services Continuous Usage -- Case Study of Finland. 201649 th Hawaii International Conference on System Sciences (HICSS), 1497-1506. https://doi.org/10.1109/HICSS.2016.189

Shaikh, A. A., Karjaluoto, H., \& Chinje, N. B. (2015a). Consumers' perceptions of mobile banking continuous usage in Finland and South Africa. International Journal of Electronic Finance, 8(2/3/4), 149. https://doi.org/10.1504/IJEF.2015.070528 
Shaikh, A. A., Karjaluoto, H., \& Chinje, N. B. (2015b). Continuous mobile banking usage and relationship commitment-A multi-country assessment. Journal of Financial Services Marketing, 20(3), 208-219. https://doi.org/10.1057/fsm.2015.14

Shareef, M. A., Baabdullah, A., Dutta, S., Kumar, V., \& Dwivedi, Y. K. (2018). Consumer adoption of mobile banking services: An empirical examination of factors according to adoption stages. Journal of Retailing and Consumer Services, 43(March), 54-67. https://doi.org/10.1016/j.jretconser.2018.03.003

SooCheong (Shawn) Jang, Y. N. (2009). Perceived quality, emotions, and behavioral intentions: Application of an extended Mehrabian-Russell model to restaurants. Journal of Business Research, 62(1), 451-460. https://doi.org/10.1016/j.tele.2014.05.003

Srivastava, A. (2013). Mobile Banking and Sustainable Growth. American Journal of Economics and Business Administration, 5(3), 89-94. https://doi.org/10.3844/ajebasp.2013.89.94

Susanto, A., Chang, Y., \& Ha, Y. (2016). Determinants of continuance intention to use the smartphone banking services An extension to the expectation-confirmation model. Industrial Management \& Data Systems, Vol. 116(3), 508-525. https://doi.org/10.1108/JEIM-04-2015-0035

Tam, C., \& Oliveira, T. (2017). Literature review of mobile banking and individual performance. International Journal of Bank Marketing, 00-00. https://doi.org/10.1108/IJBM-09-2015-0143

Teo, T. S. H., Limb, V. K. G., \& Lai, R. Y. C. (1999). Intrinsic and extrinsic motivation in Internet usage Thompson. IEE Conference Publication, 27, 25-37. https://doi.org/10.1016/S0305-0483(98)00028-0

Thatcher, J. B., \& Perrewe, P. L. (2002). An Empirical Examination of Individual Traits as Antecedents to Computer Anxiety and Computer Self-Efficacy. MIS Quarterly, 26(4), 381. https://doi.org/10.2307/4132314

Thong, J. Y. L., Hong, S. J., \& Tam, K. Y. (2006). The effects of post-adoption beliefs on the expectation-confirmation model for information technology continuance. International Journal of Human Computer Studies, 64(9), 799-810. https://doi.org/10.1016/j.ijhcs.2006.05.001

Tran, H. T. T., \& Corner, J. (2016). The impact of communication channels on mobile banking adoption. International Journal of Bank Marketing, 34(1), 78-109.

Wang, W., Ngai, E. W. T., \& Wei, H. (2012). Explaining Instant Messaging Continuance Intention: The Role of Personality. International Journal of Human-Computer Interaction, 28(8), 500-510. https://doi.org/10.1080/10447318.2011.622971

Wijesundara, T. R., \& Xixiang, S. (2018). Social Networking Sites Acceptance: The Role of Personal Innovativeness in Information Technology. International Journal of Business and Management, 13(8), 75. https://doi.org/10.5539/ijbm.v13n8p75

World-Bank, G. F. R. of the. (2018). The Little Data Book on Financial Inclusion Global Findex2018. https://doi.org/10.1596/978-1-4648-0552-3

$\mathrm{Xu}, \mathrm{H} .$, \& Gupta, S. (2009). The effects of privacy concerns and Personal Innovativeness on potential and experienced customers' adoption of location-based services. Electronic Markets, 19(2-3), 137-149. https://doi.org/10.1007/s12525-009-0012-4

Yu, T.-K., \& Fang, K. (2009). Measuring the Post-Adoption Customer Perception of Mobile Banking Services. CyberPsychology \& Behavior, 12(1), 33-35. https://doi.org/10.1089/cpb.2007.0209

Yuan, S., Liu, Y., Yao, R., \& Liu, J. (2014). An investigation of users' continuance intention towards mobile banking in China. Information Development, 32(1), 20-34. https://doi.org/10.1177/0266666914522140

Zhang, T., Lu, C., \& Kizildag, M. (2018). Banking “ on-the-go ": examining consumers ' adoption of mobile banking services. International Journal of Quality and Service Sciences, 10(3), 279-295. https://doi.org/10.1108/IJQSS-072017-0067

Zhou, T., \& Liu, Y. (2014). Examining continuance usage of mobile banking from the perspectives of ECT and flow. International Journal of Services, Technology and Management, 20(4-6), 199-214. https://doi.org/10.1504/IJSTM.2014.068844

Zhou, T., \& Liu, Y. (2014). Examining continuance usage of mobile banking from the perspectives of ECT and flow. International Journal of Services Technology and Management, 20(4/5/6), 199.

https://doi.org/10.1504/IJSTM.2014.068844 